\title{
Pengembangan Buku Ajar Matematika Dasar Berbasis Kontekstual Project Untuk Meningkatkan Keterlibatan Mahasiswa Dalam Pembelajaran
}

\author{
Sri Suryanti \\ Program Studi Pendidikan Matematika \\ Universitas Muhammadiyah Gresik \\ Email: srisuryanti@umg.ac.id
}

\begin{abstract}
Abstrak
Penelitian ini adalah penelitian pengembangan yang mengdaptasi teori Borg dan Gall. Subjek penelitian adalah mahasiswa semester dua pada Program Studi Pendidikan Matematika Universitas Muhammadiyah Gresik, tahun akademik 2019/2020. Teknik pengumpulan data menggunakan kuesioner keterlibatan mahasiswa yang terdiri dari delapan item. Hasil penelitian menunjukkan kevalidan buku ajar secara teoritis, dengan didasarkan pada penilaian ahli dengan rata-rata 90.82 dengan kategori yang sangat valid dan layak digunakan. Sedangkan hasil pengamatan terhadap keterlibatan mahasiswa dalam pembelajaran setelah digunakan buku ajar, menyebabkan keterlibatan yang sangat positif, dari indikator keseluruhan keterlibatan mahasiswa dalam pembelajaran, mendapatkan skor rata-rata 4.74 (rentang skor 1-5).
\end{abstract}

Katakunci: buku ajar, kontekstual project, keterlibatan mahasiswa

\begin{abstract}
This research is a development research that adapts the theory of Borg and Gall. The research subjects were second semester students in the Mathematics Education Study Program of The University of Muhammadiyah Gresik, academic year 2019/2020. Data collection techniques use a student engagement questionnaire consisting of eight items. The results showed the validity of textbooks theoretically, based on expert assessments with an average of 90.82 with a very valid category and worth using. While the results of observations on student involvement in learning after the use of teaching books, led to a very positive involvement, from the indicator of overall student involvement in learning, obtained an average score of 4.74 (score range 1-5)
\end{abstract}

Keywords: textbooks, contextual projects, student engagement

\section{PENDAHULUAN}

Mata kuliah Matematika Dasar

merupakan salah satu mata kuliah wajib dalam kurikulum program studi pendidikan matematika di seluruh perguruan tinggi di Indonesia. Mata 
Kuliah Matematika Dasar mempelajari teori-teori dasar matematika yang harus dipahami mahasiswa yang nantinya dapat digunakan untuk memecahkan teori-teori matematika yang lebih rumit. Sehingga kesuksesan belajar untuk mata kuliah ini sangatlah dibutuhkan. Salah satu factor dari kesuksesan belajar adalah tingkat keterlibatan mahasiswa dalam belajar.

Saat ini perilaku keterlibatan mahasiswa dalam pembelajaran sedang mendapat perhatian. Keterlibatan mahasiswa memiliki peranan penting dalam pembelajaran (Boekaerts, 2016); (Rashid \& Muhammad, 2016); (Fredricks, J. A., Filsecker, M., \& Lawson, 2016); (Gray \& Diloreto, n.d.);(Shernoff et al., 2016); (Bonet \& Walters, 2016); (Suryanti, Sutaji, \& Arifani, 2019); (Arifani \& Suryanti, 2019). Beberapa ahli mendefinisikan keterlibatan sebagai keterlibatan mahasiswa dalam proses pembelajaran pada kegiatan akademik dan kegiatan non akademik yang terlihat melalui tingkah laku, emosi, dan kognitif yang ditampilkan mahasiswa di lingkungan sekolah dan kelas (Strauss \& Volkwein, 2004); (Reeve \& Tseng, 2011); (Christenson, Wylie, \& Reschly, 2012). Namun demikian, terdapat hasil penelitian di Amerika Serikat yang cukup mengejutkan, bahwa keterlibatan mahasiswa tidak memiliki pengaruh yang signifikan terhadap kesuksesan siswa (Keller, 2017).

Selama mengampu Mata kuliah ini, peneliti telah mengembangkan modul Matematika Dasar yang terinci dalam beberapa modul. Modul yang telah dikembangkan ini berisi uraian materi, latihan soal disetiap akhir materi, serta tindak lanjut hasil belajar, yang digunakan sebagai referensi utama mahasiswa.

Referensi yang ada terkait materi yang ada yang dalam mata Kuliah Matematika Dasar yaitu Trigonometri dan Fungsi masih sangat terbatas, sehingga belum mampu memenuhi kebutuhan mahasiswa, Oleh karena itu sangat perlu dikembangkan buku ajar yang dapat memenuhi kebutuhan mahasiswa serta sesuai dengan karakteristik mahasiswa. Pengembangan yang akan dilakukan peneliti menggunakan pendekatan pembelajaran berbasis kontekstual project. Pembelajaran berbasis project dapat meningkatkan aktivitas siswa dalam pembelajaran. Penggunaan project dalam perkuliahan memiliki beberapa keunggulan antara lain memberi kesempatan kepada mahasiswa untuk menghubungkan 
masalah dengan kehidupan sehari-hari. Project juga dapat memotivasi mahasiswa dalam belajar secara mandiri. Penggunaan project memberi kesempatan kepada mahasiswa untuk mendemonstrasikan kemampuannya dalam mengkomunikasikan ide-ide matematika baik secara tulisan maupun lisan (Bush, W. S \& Greer, 1999). Dengan pengembangan menggunakan pendekatan project based learning diharapkan mahasiswa akan terlibat penuh dalam pembelajaran.

Project Based Learning dirancang untuk digunakan pada permasalahan kompleks yang diperlukan pelajaran dalam melakukan investigasi dan memahaminya. Dalam Project Based Learning, mahasiswa mengembangkan sendiri investigasi mereka bersama rekan kelompok maupun secara individual, sehingga mahasiswa secara otomatis akan mengembangkan pula kemampuan riset mereka. Mahasiswa secara aktif terlibat dalam proses pendefinisian masalah, pemecahan masalah, pengambilan keputusan, dan aktivitas investigatif lainnya. Mereka didorong untuk memunculkan ide-ide secara solusi realistis.

Menurut Stripling, dkk. dalam Majid (Majid, 2014), karakteristik Project Based Learning yang efektif adalah 1) mengarahkan mahasiswa untuk menginvestigasi ide dan pertanyaan penting; 2) merupakan proses inkuiri; 3) terkait dengan kebutuhan dan minat mahasiswa; 4) berpusat pada mahasiswa dengan membuat produk dan melakukan presentasi secara mandiri; 5) menggunakan keterampilan berfikir kreatif, kritis, dan mencari informasi untuk melakukan investigasi, menarik kesimpulan, dan menghasilkan produk; 6) terkait dengan permasalahan dan isu dunia nyata yang autentik.

Kontektual Project Based adalah model pembelajaran yang menggunakan proyek/kegiatan sebagai media, yang mana proyek yang diberikan berdasarkan pada masalah kontekstual. Dosen menugaskan mahasiswa untuk melakukan eksplorasi, penilaian, interpretasi, sistesis, dan informasi untuk menghasilkan berbagai bentuk hasil belajar. Model pembelajaran ini menggunakan masalah sebagai langkah awal dalam mengumpulkan dan mengintegrasikan pengetahuan baru berdasarkan pengalamannya dalam berkreativitas secara nyata (Hosnan, 2014).

Kontekstual Project Based Learning merupakan model pembelajaran yang diorientasikan untuk mengembangkan kemampuan dan keterampilan belajar 
para mahasiswa melalui serangkaian kegiatan merencanakan, melaksanakan penelitian, dan menghasilkan produk tertentu yang dibingkai dalam satu wadah berupa proyek pembelajaran pada masalah-masalah kontekstual.

Keterlibatan mahasiswa dalam pembelajaran sangatlah penting. Keterlibatan mahasiswa merupakan salah satu faktor penentu dalam kesuksesan belajar mahasiswa (Webber, K.L, Krylow, R.B., Zhang, 2013). Ketika mahasiswa terlibat dalam proses pembelajaran, maka dia akan menyenangi pembelajaran tersebut hingga tuntas (Pascarella, E. T., \& Terenzini, 2005);(Roberts \& McNeese, 2010).

Astin (Astin, 1984) mendefinisikan keterlibatan mahasiswa sebagai sejumlah energi baik fisik maupun psikologis yang dicurahkan oleh siswa untuk memperoleh pengalaman akademik. Siswa dapat terlibat bahkan terikat dengan kehidupan kampus melalui pelayanan pembelajaran yang baik, pembelajaran yang memberikan kesempatan mahasiswa untuk mengeksplor kemampuannya (Kuh, G. D., Kinzie, J., Schuh, J. H., \& Whitt, 2011); (Kuh, G. D., \& Hu, 2001). Sehingga keterlibatan siswa ini perlu terus diupayakan, yaitu dengan terus meningkatkan kualitas pembelajaran, meningkatkan peran dosen dalam pembelajaran dan memberikan perhatian yang lebih kepada mahasiswa.

Keterlibatan mahasiswa ini dalam proses pembelajaran akan berdampak pada peningkatan retensi mahasiswa (Mortenson, 2005), yang akhirnya berdampak kepada hasil belajar dan kualitas mahasiswa itu sendiri. Ada beberapa unsur penting dalam keterlibatan mahasiswa, menurut Fletcher (Fletcher, 2004) yaitu a) Learning yaitu keterlibatan mahasiswa dapat mengembangkan pembelajaran dengan ketrampilan yang kompleks untuk siswa. Lingkungan pembelajaran yang memberdayakan siswa sebagai pembelajar aktif, guru dan juga pemimpin; b) Partnership yaitu melibatkan siswa dengan orang dewasa sebagai mitra setara sepanjang pendidikan; c) Equity yaitu keterlibatan siswa ini berkontribusi untuk semua siswa tanda ada diskrimasi baik ras, suku, budaya, jenis kelamin, agama, status ekonomi dan lain-lain; d) Infusion yaitu keterlibatan ini mampu meningkatkan perubahan sikap yang mendalam, koheren dan sistematis; e) Quality yaitu keterlibatan ini berusaha untu terus menangani masalah 
pendidikan yang penting; f) Evidence yaitu keterlibatan ini memiliki bukti efektivitas yang dapat diukur dan memenuhi standar umum yang berlaku.

Sedangkan Trowler (Trowler, 2010) membedakan keterlibatan siswa menjadi tiga yaitu keterlibatan positif, tidak ada keterlibatan dan keterlibatan negatif. Fredricks, Blumenfeld and Paris (Fredricks, J. A., Blumenfeld, P. C., \& Paris, 2004) mengidentifikasi ada tiga ukuran untuk menyatakan bahwa siswa terlibat dalam pembelajaran; a) Perilaku siswa. Perilaku disini berarti siswa memiliki perilaku yang positif seperti mematuhi peraturan, hadir tepat waktu dan tidak mengganngu jalannya pembelajaran; b) Emosi siswa. Siswa yang terlibat secara emosi akan menunjukkan reaksi yang positif seperti menunjukkan minat dan menikmati proses pembelajaran; c) Kognitif siswa. Siswa yang terlibat secara kognitif akan mengeluarkan seluruh kemampuannya dalam pembelajaran dan menyukai tantangan.

Lebih jauh, National Suvey of Stdent Engagement (NSEE) telah merumuskan sepuluh indikator untuk keterlibatan siswa dalam pembelajaran, yaitu 1) higher-order learning; 2) Reflective \& integrative Learning; 3) Learning Strategies; 4) Quantitative Reasoning;
5) Collaborative Learning; 6) Discussions with diverse other; 7) student-faculty interaction; 8) Effective teaching parctices; 9) Quality of interactions; 10) supportive environment. Masing-masing indikator indikator ini dijabarkan kembali dalam beberapa item. Indikator pertama terdiri dari 4 item, indikator kedua terdiri dari 7 item, indikator ketiga terdiri dari 3 item, indikator keempat terdiri dari 3 item, indikator kelima terdiri dari 4 item, indikator keenam terdiri dari 4 item, indikator ketujuh terdiri dari 4 item, indikator kedelapan terdiri dari 5 item, indikator kesembilan terdiri dari 5 item, dan indikator kesepuluh terdiri dari 8 item. Sehingga total keseluruhan adalah 47 item.

Beberapa tahun terakhir, telah banyak dilakukan penelitian tentang keterlibatan siswa dalam belajar. Roberts (Roberts \& Mcneese, 2010), dalam penelitiannya dengan tujuan untuk mengetahui keterlibatan mahasiswa berdasarkan pada statusnya (reguler dan transfer), temuan dari penelitiannya adalah mahasiswa reguler memiliki keterlibatan yang tinggi, sedangkan mahasiswa transfer dari perguruan tinggi lain memiliki keterlibatan yang rendah. Dalam penelitian lain (Zhao \& Kuh, 2004) 
telah melakukan penelitian tentang hubungan antara komunitas belajar terhadap keterlibatan mahasiswa, berdasarkan penelitian mereka ditemukan bahwa komunitas belajar berkorelasi positif terhadap keterlibatan siswa.

\section{METODE}

Rancangan penelitian dilakukan oleh peneliti adalah mengadaptasi dari langkah-langkah penelitian dan pengembangan yang dikembangkan oleh Borg and Gall (Borg \& Gall, 2003) dengan beberapa pembatasan. Sedangkan, kriteria kevalidan buku ajar hasil pengembangan, menggunakan kriteria berikut:

Tabel 1 Kriteria kevalidan buku ajar

\begin{tabular}{ll}
\hline Skor akhir & \multicolumn{1}{c}{ Klasifikasi } \\
\hline $81-100$ & Sangat valid dan dapat digunakan \\
$61-80$ & Cukup valid, dan dapat digunakan \\
& dengan sedikit revisi \\
$41-60$ & Sedikit valid, tidak bias digunakan \\
$21-40$ & Tidak valid dan tidak bias digunakan \\
$0-20$ & Sangat tidak valid, tidak dapat \\
& digunakan \\
\hline
\end{tabular}

Selanjutnya, untuk mengukur keterlibatan mahasiswa dalam pembelajaran setelah menggunakan buku ajar, peneliti menggunakan kuesioner keterlibatan siswa dalam pembelajaran yang diisi oleh mahasiswa secara online. Survei keterlibatan mahasiswa terdiri dari delapan item. Dari kedelapan item tersebut, dirinci dengan rincian tiga item untuk mengukur keterlibatan siswa dalam tahap persiapan pembelajaran, dua item untuk mengukur keterlibatan mahasiswa dalam proses pembelajaran, dan tiga item untuk mengukur keterlibatan mahasiswa di akhir pembelajaran. Setiap item dalam kuesioner ini menggunakan skala Likert $1-5$.

Sedangkan subjek yang menggunakan buku ajar hasil pengembangan adalah mahasiswa semester dua yang mengambil mata kuliah Matematika Dasar, sebanyak 20 mahasiswa.

\section{HASIL DAN PEMBAHASAN}

\section{Hasil pengembangan buku ajar}

Langkah awal penelitian ini adalah pendataan dengan kajian lapangan dan tinjauan literatur untuk mengetahui informasi tentang pelaksanaan perkuliahan pada mata kuliah Matematika Dasar. Pada tahap survei lapangan, kegiatan tersebut adalah wawancara kepada dosen dan beberapa mahasiswa. Data temuan digunakan sebagai bahan untuk merencanakan merancang produk buku ajar matematika dasar dengan pendekatan 
kontekstual project. Setelah produk awal selesai, kemudian dilakukan validasi oleh ahli, dalam hal ini 4 dosen pendidikan matematika. Saran dari para ahli media digunakan untuk merevisi produk, yang mana validasi ini dilakukan dengan mendistribusikan kuesioner validasi, hingga diperoleh data berikut:

Table 2. Hasil kuesioner validasi ahli

\begin{tabular}{lll}
\hline No & Validator & Nilai \\
\hline 1 & Validator 1 & 90.32 \\
2 & Validator 2 & 91.25 \\
3 & Validator 3 & 92.05 \\
4 & Validator 4 & 90.57
\end{tabular}

Berdasarkan table 2, diperoleh rata - rata skor hasil validasi dari para ahli adalah 90.82 yang artinya buku ajar hasil pengembangan dalam kategori sangat valid dan dapat digunakan.

\section{Hasil analisis keterlibatan} mahasiswa dalam pembelajaran

Hasil kuesioner keterlibatan siswa dalam pembelajaran disajikan dalam tabel 3 berikut:
Tabel 3. Hasil kuesioner keterlibatan siswa

\begin{tabular}{ccccccc}
\hline Item & \multicolumn{5}{c}{ Skor } & $\begin{array}{c}\text { Rata- } \\
\text { rata }\end{array}$ \\
\cline { 2 - 7 } $\mathrm{Q}_{1}$ & $0 \%$ & $0 \%$ & $0 \%$ & $20 \%$ & $80 \%$ & 4.80 \\
$\mathrm{Q}_{2}$ & $0 \%$ & $0 \%$ & $0 \%$ & $20 \%$ & $80 \%$ & 4.80 \\
$\mathrm{Q}_{3}$ & $0 \%$ & $0 \%$ & $0 \%$ & $10 \%$ & $90 \%$ & 4.87 \\
$\mathrm{Q}_{4}$ & $0 \%$ & $0 \%$ & $10 \%$ & $20 \%$ & $73 \%$ & 4.67 \\
$\mathrm{Q}_{5}$ & $0 \%$ & $0 \%$ & $0 \%$ & $40 \%$ & $60 \%$ & 4.60 \\
$\mathrm{Q}_{6}$ & $0 \%$ & $0 \%$ & $0 \%$ & $10 \%$ & $90 \%$ & 4.87 \\
$\mathrm{Q}_{7}$ & $0 \%$ & $0 \%$ & $0 \%$ & $10 \%$ & $90 \%$ & 4.87 \\
$\mathrm{Q}_{8}$ & $0 \%$ & $0 \%$ & $0 \%$ & $55 \%$ & $45 \%$ & 4.47 \\
\hline
\end{tabular}

Keterlibatan mahasiswa dalam pembelajaran terlihat dalam tiga kondisi, yaitu pada saat persiapan belajar, selama proses pembelajaran dan ketika pembelajaran berakhir. Mahasiswa melibatkan diri sejak awal pembelajaran melalui kesediaan mahasiswa membaca materi dalam buku ajar sebelum perkuliahan dan kedisiplinan mahasiswa yang ditunjukkan dengan datang tepat waktu selama perkuliahan.

\section{Analisis keterlibatan mahasiswa dalam pembelajaran}

Dari tabel 3, pertanyaan pertama mendapatkan skor rata-rata 4,80 dengan rincian $80 \%$ responden memberikan skor 5 , dan $20 \%$ memberikan skor 4 . Ini menunjukkan bahwa siswa telah melibatkan diri dalam pembelajaran, dengan membuktikan siswa telah 
membaca materi pada buku ajar sebelum perkuliahan. Selanjutnya, pada pertanyaan kedua adalah terkait dengan disiplin mahasiswa dalam perkuliahan, $80 \%$ mahasiswa datang tepat waktu, dan $20 \%$ sisanya mengatakan mereka terlambat untuk menghadiri perkuliahan. Kemudian pertanyaan ketiga tentang minat mahasiswa terhadap buku ajar menunjukkan hasil yang sangat positif, $90 \%$ siswa sangat senang, dan $10 \%$ sisanya menjawab cukup senang dengan buku ajar yang mereka gunakan.

Pertanyaan keenam dan ketujuh adalah melihat keterlibatan siswa dalam proses pembelajaran. Pertanyaan keenam yaitu tentang sikap mahasiswa pada saat pembelajaran berlangsung, $\quad 90 \%$ mahasiswa memperhatikan penjelasan dosen, sedangkan 10\% mahasiswa terkadang memperhatikan penjelasan dosen selama pembelajaran. Selanjutnya, untuk pertanyaan ketujuh, tentang tanggapan mahasiswa selama diskusi dan presentasi, 90\% mahasiswa secara aktif terlibat dalam pembicaraan dan presentasi, sementara 10\% menyatakan bahwa mereka kadangkadang terlibat.

Indikator keterlibatan mahasiswa di akhir pembelajaran adalah pada pertanyaan keempat, kelima dan kedelapan, yang terkait dengan 'kesediaan mahasiswa untuk membuat ringkasan materi dalam bahasa mereka, kesediaan mahasiswa untuk melakukan latihan dan tes formatif yang terdapat dalam buku ajar. Dalam pertanyaan keempat, $70 \%$ siswa selalu membuat ringkasan materi, $20 \%$ siswa kadangkadang membuat ringkasan materi, dan $10 \%$ sisanya pernah membuat ringkasan materi. Selanjutnya, pertanyaan kelima adalah tentang kesediaan siswa untuk mengerjakan soal latihan, 60\% siswa mengerjakan soal latihan di setiap akhir materi, sedangkan $40 \%$ siswa hanya mengerjakan beberapa latihan yang diberikan. Pertanyaan terakhir, yaitu. Kesediaan siswa untuk mengerjakan tes formatif sebagai tantangan dalam buku ajar, $45 \%$ siswa tertarik untuk mengerjakan tes formatif, sementara $55 \%$ sisanya menunjukkan lebih sedikit minat untuk mengerjakan tes formatif.

\section{PENUTUP}

\section{Simpulan}

Dari hasil penelitian yang telah dilakukan dapat disimpulkan bahwa keterlibatan mahasiswa dalam pembelajaran dengan menggunakan Buku Ajar hasil pengembangan menunjukkan keterlibatan positif, yaitu mahasiswa dengan kesediaannya membaca materi sebelum perkuliahan. 
Mengajarkan materi perkuliahan dengan menggunakan Buku Ajar ini mendorong mahasiswa untuk membacanya perkuliahan sehingga keterlibatan mahasiswa dalam pembelajaran dapat ditingkatkan. Dari indikator keseluruhan keterlibatan mahasiswa dalam pembelajaran, skor rata-rata adalah 4,7 (rentang skor 1-5).

\section{Saran}

Seiring dengan perkembangan teknologi yang sangat pesat saat ini, perlu dilakukan penelitian lanjutan pada pengembangan bahan ajar berbasis teknologi.

\section{Ucapan Terimakasih}

Ucapan terimakasih yang mendalam kepada Universitas Muhammadiyah Gresik melalui LPPM yang telah mendanai secara penuh kegiatan penelitian ini.

\section{DAFTAR PUSTAKA}

Arifani, Y., \& Suryanti, S. (2019). The Influence of Male and Female ESP Teachers , Creativity toward Learners , Involvement. International Journal of Instruction, 12(1), 237-250.

Astin, A. W. (1984). Student Involvement: A Developmental Theory for Higher Education,
(July), 518-529.

Boekaerts, M. (2016). Engagement as an inherent aspect of the learning process. Learning and Instruction, 43, 76-83.

Bonet, G., \& Walters, B. (2016). High impact practices: Student enagagement and retention. College Student Journal, 50(2), 224-235.

https://doi.org/10.1145/3137003.3

137007

Borg \& Gall. (2003). Education Research. New York: Allyn and Bacon.

Bush, W. S \& Greer, A. S. (1999). Mathematics Assessment. Reston:NCTM.

Christenson, S. L., Wylie, C., \& Reschly, A. L. (2012). Handbook of Research on Student Engagement. Handbook of Research on Student Engagement. https://doi.org/10.1007/978-14614-2018-7

Fletcher, A. (2004). Meaningful student involvement: Research Guide, 40. Retrieved from internalpdf://2004fletchermsiresearch3355968000/2004FletcherMSIRes earch.pdf

Fredricks, J. A., Blumenfeld, P. C., \& Paris, A. H. (2004). School engagement: Potential of the 
concept, state of the evidence. Review of Educational Research, 74(1), 59-109.

Fredricks, J. A., Filsecker, M., \& Lawson, M. A. Student engagement, context, and adjustment: Addressing definitional, measurement, and methodological issues (2016).

Gray, J. A., \& Diloreto, M. (n.d.). The Effects of Student Engagement, Student Satisfaction, and Perceived Learning in Online Learning Environments, 11(1).

Hosnan, M. (2014). Pendekatan saintifik dan kontekstual dalam pembelajaran abad 21. Bogor: Ghalia Indonesia.

Keller, S. (2017). Beyond the ruling class: strategic elites in modern society. Routledge.

Kuh, G. D., \& Hu, S. (2001). The effects of student-faculty interaction in the 1990s. The Review of Higher Education, 24(3), 309-332.

Kuh, G. D., Kinzie, J., Schuh, J. H., \& Whitt, E. J. (2011). Student success in college: Creating conditions that matter. John Wiley \& Sons.

Majid. (2014). Strategi pembelajaran. Bandung: PT Remaja Rosdakarya.

Mortenson, T. G. (2005). Measurements of persistence. College student retention: Formula for student success (pp. 31-60).

Pascarella, E. T., \& Terenzini, P. T. (2005). How college affects students: A third decade of research (Vol 2).

Rashid, T., \& Muhammad, H. (2016). Computers in Human Behavior Technology use, self-directed learning, student engagement and academic performance : Examining the interrelations. Computers in Human Behavior, 63, 604-612. https://doi.org/10.1016/j.chb.2016. 05.084

Reeve, J., \& Tseng, C. M. (2011). Agency as a fourth aspect of students' engagement during learning activities. Contemporary Educational Psychology, 36(4), 257-267.

https://doi.org/10.1016/j.cedpsych. 2011.05.002

Roberts, J., \& Mcneese, M. (2010). Student Involvement / Engagement in Higher Education Based on Student Origin. Research in Higher Education Journal, 1, 1-11.

Roberts, J., \& McNeese, M. N. (2010). Student involvement/engagement in higher education based on student origin. Research in Higher Education Journal, 1.

Shernoff, D. J., Kelly, S., Tonks, S. M., 
Anderson, B., Cavanagh, R. F., Sinha, S., \& Abdi, B. (2016). Student engagement as a function of environmental complexity in high school classrooms. Learning and Instruction, 43, 52-60. https://doi.org/10.1016/j.learninstr uc. 2015.12 .003

Strauss, L. C., \& Volkwein, J. F. (2004). Predictors of Student Commitment at Two-Year and Four-Year Institutions. The Journal of Higher Education, $75(2)$, 203-227. https://doi.org/10.1353/jhe.2004.0 007

Suryanti, S., Sutaji, D., \& Arifani, Y. (2019). Student's engagement behaviour and their success in abstract algebra : structural equation modelling approach. In Journal of Physics: Conference
Series, 1188

012105. https://doi.org/10.1088/1742$6596 / 1188 / 1 / 012105$

Trowler, V. (2010). Student engagement literature review, (November).

Webber, K.L, Krylow, R.B., Zhang, Q. (2013). Does involvement really matter? Indicators of college student success and satisfaction. Journal of College Student Development, 54(6), 591-611.

Zhao, C. M., \& Kuh, G. D. (2004). Adding value: Learning communities and student engagement. Research in Higher Education, 45(2), 115-138. https://doi.org/10.1023/B:RIHE.00 00015692.88534.de 